\title{
FAKTOR BUDIDAYA DAN KAITANNYA DENGAN KEPARAHAN PENYAKIT KARAT PURU PADA SENGON (Falcataria moluccana (Miq.) Barneby \& J.W. Grimes)
}

\author{
Cultivation Practices and Its Correlation to The Severity of Gall Rust Disease \\ on Falcataria moluccana (Miq.) Barneby \& J.W. Grimes)
}

\author{
Neo Endra Lelana ${ }^{1 *}$, Suryo Wiyono ${ }^{2}$, Giyanto ${ }^{2}$ dan/and Iskandar Z. Siregar ${ }^{3}$ \\ ${ }^{1}$ Pusat Penelitian dan Pengembangan Hutan, \\ Jl. Gunung Batu No. 5 Bogor, Jawa Barat, Indonesia. Telp: 0251-8633234, Faks: 0251-8638111 \\ ${ }^{2}$ Departemen Proteksi Tanaman, Fakultas Pertanian, Institut Petanian Bogor, \\ Jl. Meranti, Kampus IPB Dramaga, Bogor, Jawa Barat, Indonesia \\ ${ }^{3}$ Departemen Silvikultur, Fakultas Kehutanan, Institut Pertanian Bogor, \\ Jl. Lingkar Akademik Kampus IPB Dramaga, Bogor, Jawa Barat, Indonesia \\ *Email: neo_3L@yahoo.com
}

Tanggal diterima: 2 Agustus 2017; Tanggal direvisi: 9 Mei 2018; Tanggal disetujui: 17 Mei 2018

\begin{abstract}
Until now, gall rust disease is a major threat for Falcataria moluccana plantations in Indonesia. One of the environmental factors that can influence the development of plant diseases is the cultivation practice. However, the studies related to the influence of cultivation practice to the $\mathrm{F}$. moluccana gall rust disease are still limited. This study aimed to determine the correlation between cultivation practice to the incidence and severity of $\mathrm{F}$. moluccana gall rust disease. The incidence and severity of $\mathrm{F}$. moluccana gall rust disease were observed from 47 planting sites distributed throughout Java. Its correlation to the cultivation practice was analyzed using chi square analysis followed by coordinate analysis. The results indicated that 6 of 13 variables were significantly correlated with disease incidence. Meanwhile, only 3 of 13 variables were significantly correlated to disease severity. These factors were plant age, use of organic fertilizer, and chemical control. Based on coordinate analysis result, organic fertilizer and chemical control application showed strong association with low level disease severity.
\end{abstract}

Keywords: Chemical control, Java, organic fertilizer, plant age

\begin{abstract}
ABSTRAK
Penyakit karat puru masih menjadi permasalahan yang utama pada tanaman sengon di Indonesia. Tanaman sengon dapat diserang pada semua tingkatan umur dan telah menimbulkan kerugian yang signifikan. Salah satu faktor lingkungan yang memengaruhi perkembangan penyakit tanaman ialah faktor budidaya. Penelitian ini bertujuan untuk mengetahui hubungan antara faktor budidaya dengan insidensi dan keparahan penyakit karat puru pada sengon. Sebanyak 47 lokasi penanaman sengon yang tersebar di seluruh Jawa diamati insidensi dan keparahan penyakitnya. Hubungannya dengan faktor budidaya dianalisis menggunakan Khikuadrat yang dilanjutkan dengan analisis korespondensi. Hasil penelitian menunjukkan sebanyak 6 dari 13 variabel faktor budi daya menunjukkan korelasi yang signifikan terhadap insidensi penyakit. Sementara itu terhadap keparahan penyakit, sebanyak 3 dari 13 variabel faktor budidaya menunjukkan korelasi yang signifikan. Ketiga faktor tersebut yaitu umur tanaman, penggunaan pupuk organik, dan pengendalian kimiawi. Hasil analisis korespondensi menunjukkan faktor penggunaan pupuk organik dan pengendalian secara kimiawi berasosiasi dengan keparahan penyakit yang rendah.
\end{abstract}

Kata kunci: Jawa, pengendalian kimiawi, pupuk organik, umur tanaman 


\section{PENDAHULUAN}

Saat ini, sengon (Falcataria moluccana (Miq.) Barneby \& J.W. Grimes) menjadi salah satu komoditas kehutanan yang penting di Indonesia. Produksi kayu sengon ikut berperan signifikan dalam menyumbang produksi kayu nasional. Pertumbuhannya yang cepat menjadikan tanaman ini makin diminati oleh masyarakat, sehingga populasinya selalu meningkat setiap tahunnya. Menurut data Badan Pusat Statistik (2013), dari tahun 2003 sampai dengan tahun 2013 populasi sengon meningkat hampir lima kali lipat.

Epidemi penyakit karat puru telah menjadi ancaman yang serius terhadap pengusahaan tanaman sengon di Indonesia. Penyakit yang dapat menyerang tanaman sengon pada semua tingkatan umur ini tidak hanya menimbulkan kerugian yang signifikan, namun juga telah meresahkan petani hutan. Penyebab penyakit karat puru pada sengon pertama kali diidentifikasi sebagai cendawan Uromycladium tepperianum (Sacc.) McAlpine (Anggraeni, 2008; Rahayu, Lee, \& Shukor, 2010). Berbeda dengan jenis Uromycladium lainnya yang mempunyai kisaran inang yang sedikit, $U$. tepperianum dilaporkan mempunyai inang lebih dari seratus jenis akasia (Berndt, 2010). Pada tahun 2015, nama baru untuk patogen karat puru pada sengon diusulkan sebagai $U$. Falcatarium (Doungsa-ard et al., 2015).

Diantara beberapa faktor lingkungan yang terlibat dalam perkembangan penyakit tumbuhan, praktik budidaya memegang peranan yang penting. Faktor tersebut berpengaruh terhadap pertumbuhan dan kesiapan tanaman untuk bertahan menghadapi serangan patogen. Pendekatan dengan praktik budidaya ini menjadi pendekatan yang layak secara ekonomi di negara berkembang (El Khoury \& Makkouk, 2010). Keuntungan utama pendekatan dengan praktik budi- daya dibanding pendekatan lainnya ialah aplikasinya yang mudah dan murah. Pada kasus penyakit karat puru sengon, seperti pada kasus penyakit tanaman hutan lainnya, pengendalian dengan pendekatan kimiawi tunggal sulit dilakukan dalam jangka waktu yang lama. Selain biaya yang mahal, pendekatan tersebut juga berpotensi mempunyai dampak negatif terhadap lingkungan. Berbagai penelitian telah menunjukkan bahwa praktik budi daya berasosiasi dengan tingkat keparahan penyakit tanaman, seperti pada penyakit gosong padi (Brooks, Anders, \& Yeater, 2009), busuk batang Sclerotinia pada kedelai (Beruski, Pereira, Jaccoudfilho, Sartorri, \& Sentelhas, 2015), dan karat batang gandum (Tenge, Ojwang, Otaye, \& Oyoo, 2016). Pada penyakit karat puru sengon, informasi mengenai hubungan antara perkembangan penyakit dengan praktik budidaya masih terbatas. Oleh karena itu, penelitian ini bertujuan untuk mengetahui hubungan antara faktor budidaya dengan insidensi dan keparahan penyakit karat puru pada sengon.

\section{METODOLOGI}

\section{A. Waktu dan Lokasi Penelitian}

Pengamatan insidensi dan keparahan penyakit karat puru dilakukan pada tahun 2015. Penelitian dilakukan di sentra-sentra penanaman sengon di Jawa Barat, Jawa Tengah, dan Jawa Timur. Penelitian ini difokuskan di Pulau Jawa (Tabel 1), karena berdasarkan data sebaran populasi tanaman sengon di Indonesia, sekitar $90 \%$ populasi sengon berada di Pulau Jawa (Badan Pusat Statistik, 2013). Sebanyak 47 lokasi dipilih dengan metode purposive random sampling. Setiap plot diamati 30 pohon. Pengambilan sampel pohon menggunakan metode "stratified random sampling design". 
Neo Endra Lelana, Suryo Wiyono, Giyanto dan Iskandar Z. Siregar

\section{B. Pengamatan Insidensi dan} Keparahan Penyakit

Insidensi penyakit (IP) dihitung menggunakan rumus berikut:

$$
\begin{aligned}
& \mathrm{IP}=\frac{\mathrm{n}}{\mathrm{N}} \times 100 \% \text {, dengan } \\
& \text { IP = Insidensi penyakit; } \\
& \mathrm{n} \text { = Jumlah tanaman yang terserang; } \\
& \text { dan } \\
& \mathrm{N}=\text { Jumlah tanaman contoh yang } \\
& \text { diamati. }
\end{aligned}
$$

Keparahan penyakit (KP) dihitung menggunakan rumus berikut:

$$
\begin{aligned}
\mathrm{KP}= & \frac{\sum \text { ni } \mathrm{xi}}{\mathrm{N} \times \mathrm{v}} \times 100 \%, \text { dengan } \\
\mathrm{KP}= & \text { Keparahan penyakit; } \\
\mathrm{ni}= & \text { Jumlah tanaman dengan skor } \\
& \text { ke-i; } \\
\mathrm{vi}= & \text { Nilai skor penyakit (dari } 0 \\
& \text { sampai 5); } \\
\mathrm{N}= & \text { Jumlah tanaman contoh yang } \\
& \text { diamati; dan } \\
\mathrm{V}= & \text { Skor tertinggi. }
\end{aligned}
$$

Skor tingkat keparahan penyakit dihitung dengan metode Lelana, Wiyono, Giyanto, \& Siregar (2018) yang dimodifikasi. Skor tingkat keparahan penyakit dibedakan menjadi dua yaitu skor untuk tanaman berumur 1-2 tahun dan skor untuk tanaman yang berumur di atas 2 tahun. Skor tingkat keparahan karat puru untuk tanaman umur 1-2 tahun dan umur di atas 2 tahun pada Tabel 2 .

\section{Pengumpulan Data Budidaya}

Data praktik budidaya yang dilakukan dikumpulkan melalui pengamatan dan wawancara langsung dengan petani sengon pada masing-masing lokasi pengamatan penyakit karat puru. Wawancara dilakukan dengan menggunakan kuesioner berisi beberapa hal yang terkait dengan praktik budidaya yang dilakukan oleh petani sengon. Sebanyak tiga belas faktor yang terkait dengan praktik budidaya sengon tersebut disajikan pada Tabel 3. Faktor-faktor budidaya tersebut dipilih berdasarkan informasi sebelumnya yang secara umum mengindikasikan adanya peranan dari faktorfaktor tersebut dalam menekan tingkat intensitas penyakit tanaman.

Tabel (Table) 1. Lokasi penelitian (Site location)

\begin{tabular}{clc}
\hline Provinsi (Province) & \multicolumn{1}{c}{ Kabupaten (District) } & Jumlah lokasi (Number of sites) \\
\hline Jawa Barat (West Java) & Bogor & 3 \\
& Cianjur & 3 \\
& Sukabumi & 2 \\
& Bandung & 3 \\
& Garut & 4 \\
& Ciamis & 3 \\
Jawa Tengah (Central Java) & Pangandaran & 2 \\
& Majalengka & 2 \\
& Kuningan & 5 \\
& Batang & 5 \\
& Banjarnegara & 2 \\
Jawa Timur (East Java) & Purbalingga & 3 \\
& Boyolali & 2 \\
& Karanganyar & 2 \\
& Lumajang & 3 \\
& Malang & 3 \\
& Total & 47 \\
\hline
\end{tabular}


Tabel (Table) 2. Skor keparahan penyakit karat puru pada tanaman sengon (Score of gall rust disesase severity on Falcataria moluccana)

\begin{tabular}{|c|c|c|}
\hline \multirow{2}{*}{$\begin{array}{c}\text { Skor } \\
\text { (Score) }\end{array}$} & \multicolumn{2}{|c|}{ Deskripsi (Description) } \\
\hline & Umur $\leq 2$ tahun $($ Age $\leq 2$ years $)$ & Umur $>2$ tahun $($ Age $>2$ years $)$ \\
\hline 0 & Tanaman tidak terserang (No diseases) & Tanaman tidak terserang (No diseases) \\
\hline 1 & $\begin{array}{l}\text { Serangan pada daun, ranting, dan cabang } \\
\text { sebanyak } \leq 10 \% \text { (Galls on the leaves, } \\
\text { twigs, or branches were } \leq 10 \% \text { ) }\end{array}$ & $\begin{array}{l}\text { Serangan pada daun, ranting, dan cabang sebanyak } \\
\leq 20 \% \text { (Galls on the leaves, twigs, or branches } \\
\text { were } \leq 20 \% \text { ) }\end{array}$ \\
\hline 2 & $\begin{array}{l}\text { Serangan pada daun, ranting, dan cabang } \\
\text { sebanyak 11-20\% (Galls on the leaves, } \\
\text { twigs, or branches were 11-20\%) }\end{array}$ & $\begin{array}{l}\text { Serangan pada daun, ranting, dan cabang sebanyak } \\
21-50 \% \text { (Galls on the leaves, twigs, or branches } \\
\text { were } 21-50 \%)\end{array}$ \\
\hline 3 & $\begin{array}{l}\text { Serangan pada daun, ranting, dan cabang } \\
\text { sebanyak } 21-50 \% \text { (Galls on the leaves, } \\
\text { twigs, or branches were } 21-50 \% \text { ) }\end{array}$ & $\begin{array}{l}\text { Serangan pada daun, ranting, dan cabang sebanyak } \\
>50 \% \text {, atau pada batang atas (bukan batang bebas } \\
\text { cabang) (Galls on the leaves, twigs, or branches } \\
\text { were }>50 \% \text {, one or more on the top trunk) }\end{array}$ \\
\hline 4 & $\begin{array}{l}\text { Serangan pada daun, ranting, dan cabang } \\
\text { sebanyak }>50 \% \text { (Galls on the leaves, } \\
\text { twigs, or branches were }>50 \% \text {, and no } \\
\text { disease on trunk) }\end{array}$ & $\begin{array}{l}\text { Serangan pada batang bebas cabang, sebanyak } \leq 2 \\
\text { kelompok( } \leq 2 \text { galls on branch-free trunk) }\end{array}$ \\
\hline 5 & $\begin{array}{l}\text { Serangan pada batang utama } \geq 1 \\
\text { kelompok }(1 \text { or more galls on trunk })\end{array}$ & $\begin{array}{l}\text { Serangan pada batang bebas cabang } \geq 3 \\
\text { kelompok }(\geq 3 \text { galls on branch-free trunk) }\end{array}$ \\
\hline
\end{tabular}

\section{Analisis Korelasi}

Nilai insidensi dan keparahan penyakit dikelompokkan ke dalam tiga kelas yaitu rendah, sedang dan tinggi (Tabel 4). Analisis korelasi dilakukan dengan analisis Khi-kuadrat $\left(\chi^{2}\right)$. Nilai faktor-faktor budidaya pertama-tama dikelompokkan ke dalam kelas-kelas (Tabel 3). Data selanjutnya disusun dalam suatu tabel kontingensi dengan kelas insidensi dan keparahan penyakit sebagai kolom dan faktor-faktor sebagai baris. Faktor-faktor yang menunjukkan adanya hubungan yang signifikan pada uji Khi-kuadrat selanjutnya dianalisis dengan analisis korespondensi. Analisis Khi-kuadrat dan korespondensi dilakukan menggunakan program SPSS Version 20 (IBM Corp, 2011).

\section{HASIL DAN PEMBAHASAN}

\section{A. Hasil}

1. Analisis korelasi faktor budidaya dengan insidensi dan keparahan penyakit

Hasil analisis korelasi faktor budidaya dengan insidensi dan keparahan penyakit disajikan pada Tabel 5. Se- banyak enam faktor budidaya secara signifikan berkorelasi dengan insidensi penyakit. Faktor-faktor tersebut yaitu umur tanaman, penggunaan pupuk organik, pengendalian puru secara kimiawi, pemangkasan puru, jenis tanaman pencampur dan kemiringan lahan. Sementara itu, beberapa faktor seperti asal bibit, jarak tanam, pola tanam, tutupan lahan, penggunaan pupuk kimia, penggunaan herbisida dan sejarah lahan menunjukkan korelasi yang tidak signifikan.

Untuk keparahan penyakit, hanya terdapat tiga faktor budidaya yang secara signifikan berkorelasi. Faktor-faktor tersebut yaitu umur tanaman, penggunaan pupuk organik dan pengendalian karat puru secara kimiawi. Hasil ini berbeda dengan hasil analisis pada insidensi penyakit dimana faktor-faktor yang berkorelasi signifikan terhadap insidensi penyakit, seperti pemangkasan tanaman yang kena penyakit karat puru, sejarah lahan dan kemiringan lahan tidak menunjukkan korelasi yang signifikan terhadap keparahan penyakit. Faktor-faktor yang berkorelasi signifikan pada insidensi dan keparahan penyakit selanjutnya ditabulasikan pada Tabel 6 . 
Tabel (Table) 3. Faktor-faktor praktik budidaya dan pengelompokan kelas kategori (List of cultivation practice factors and their classification)

\begin{tabular}{|c|c|c|c|}
\hline No. & Faktor (Factor) & $\begin{array}{l}\text { Kode } \\
(\text { Code })\end{array}$ & Kelas kategori (Category) \\
\hline \multirow[t]{3}{*}{1.} & \multirow{3}{*}{$\begin{array}{l}\text { Kemiringan lahan (Land } \\
\text { slope) }\end{array}$} & K1 & Datar (Flat) \\
\hline & & K2 & Landai (Ramps) \\
\hline & & K3 & Curam (Steep) \\
\hline \multirow[t]{2}{*}{2.} & \multirow{2}{*}{$\begin{array}{l}\text { Umur tanaman } \\
\text { (Plant age) }\end{array}$} & $\mathrm{Y} 1$ & $1-2$ tahun $(1-2$ years old $)$ \\
\hline & & $\mathrm{Y} 2$ & $>2$ tahun $(>2$ years old $)$ \\
\hline \multirow[t]{4}{*}{3.} & \multirow{4}{*}{$\begin{array}{l}\text { Asal bibit } \\
\text { (Source of seeds) }\end{array}$} & B1 & Membibitkan sendiri (Own nurseries) \\
\hline & & B2 & Membeli dari pasaran (Market) \\
\hline & & B3 & Bantuan Pemerintah (Government program) \\
\hline & & B4 & Trubusan (Sprouting) \\
\hline \multirow[t]{2}{*}{4.} & \multirow{2}{*}{$\begin{array}{l}\text { Pola tanam } \\
\text { (Cropping pattern) }\end{array}$} & M1 & Monokultur (Monoculture) \\
\hline & & M2 & Agroforestri (Agroforestry) \\
\hline \multirow[t]{2}{*}{5 . } & \multirow{2}{*}{$\begin{array}{l}\text { Jarak tanam } \\
\text { (Plant spacing) }\end{array}$} & $\mathrm{J} 1$ & Rapat $($ Tight $)(<2 \times 3 \mathrm{~m})$ \\
\hline & & $\mathrm{J} 2$ & Renggang(Thin) $(\geq 2 \times 3 \mathrm{~m})$ \\
\hline \multirow[t]{3}{*}{6.} & \multirow{3}{*}{$\begin{array}{l}\text { Tutupan lahan } \\
\text { (Land cover) }\end{array}$} & L1 & Rendah $($ Low $)(0-30 \%)$ \\
\hline & & L2 & Sedang(Moderate) $(30<\mathrm{x}<70 \%)$ \\
\hline & & L3 & Tinggi $($ High $)(70 \%)$ \\
\hline \multirow[t]{3}{*}{7.} & \multirow{3}{*}{$\begin{array}{l}\text { Sejarah lahan } \\
\text { (Land history) }\end{array}$} & S1 & Lahan tidur (Unusable land) \\
\hline & & S2 & Lahan pertanian (Agriculture land) \\
\hline & & S3 & Perkebunan/Tanaman Hutan (Plantation/Forest Land) \\
\hline \multirow[t]{2}{*}{8.} & \multirow{2}{*}{$\begin{array}{l}\text { Jenis tanaman pencampur } \\
\text { (Species of mixed plant) }\end{array}$} & K1 & Tanaman non kayu (Non timber plant) \\
\hline & & K2 & Pohon (Timber plant) \\
\hline \multirow[t]{2}{*}{9.} & \multirow{2}{*}{$\begin{array}{l}\text { Penggunaan pupuk kimia } \\
\text { (Use of chemical } \\
\text { fertilizer) }\end{array}$} & $\mathrm{C} 1$ & Tidak digunakan (Not used) \\
\hline & & $\mathrm{C} 2$ & Digunakan(Used) \\
\hline \multirow[t]{2}{*}{10.} & \multirow{2}{*}{$\begin{array}{l}\text { Penggunaan pupuk organik } \\
\text { (Use of organic fertilizer) }\end{array}$} & $\mathrm{O} 1$ & Tidak digunakan (Not used) \\
\hline & & $\mathrm{O} 2$ & Digunakan(Used) \\
\hline \multirow[t]{2}{*}{11.} & \multirow{2}{*}{$\begin{array}{l}\text { Penggunaan herbisida (Use } \\
\text { of Herbicides) }\end{array}$} & $\mathrm{R} 1$ & Tidak digunakan(Not used) \\
\hline & & $\mathrm{R} 2$ & Digunakan $($ Used $)$ \\
\hline \multirow[t]{2}{*}{12.} & \multirow{2}{*}{$\begin{array}{l}\text { Pengendalian dengan } \\
\text { fungisida } \\
\text { (Use of fungicides) }\end{array}$} & $\mathrm{F} 1$ & Tidak digunakan(Not used) \\
\hline & & $\mathrm{F} 2$ & Digunakan (Used) \\
\hline & \multirow{2}{*}{$\begin{array}{l}\text { Pemangkasan puru } \\
\text { (Gallspruning) }\end{array}$} & W1 & Tidak dilakukan (Not done) \\
\hline & & W2 & Dilakukan (Done) \\
\hline
\end{tabular}

Tabel (Table) 4. Klasifikasi insidensi dan keparahan penyakit karat puru pada sengon (Classification of gall rust disease incidence and severity)

\begin{tabular}{lccc}
\hline \multicolumn{1}{c}{ Kategori (Category) } & Kode (Code) & $\begin{array}{c}\text { Insidensi penyakit } \\
\text { (Disease incidence) (IP) }\end{array}$ & $\begin{array}{c}\text { Keparahan penyakit (Disease } \\
\text { severity) (KP) }\end{array}$ \\
\hline Rendah (Low) & 1 & $\mathrm{IP} \leq 25 \%$ & $\mathrm{KP} \leq 20 \%$ \\
Sedang (Moderate) & 2 & $26 \leq \mathrm{IP} \leq 60 \%$ & $21 \leq \mathrm{KP} \leq 50 \%$ \\
Tinggi (High) & 3 & $\mathrm{IP} \geq 61 \%$ & $\mathrm{KP} \geq 51 \%$ \\
\hline
\end{tabular}


Tabel (Table) 5. Kaitan antara faktor budidaya dengan keparahan penyakit karat puru (Correlation between cultivation practices and gall rust disease)

\begin{tabular}{|c|c|c|c|c|}
\hline \multirow[b]{2}{*}{ Faktor (Factor) } & \multicolumn{2}{|l|}{ IP } & \multicolumn{2}{|c|}{ KP } \\
\hline & $\begin{array}{l}\text { Khi-kuadrat } \\
\text { (Chi-square) }\end{array}$ & $\mathrm{P}$ & $\begin{array}{l}\text { Khi-kuadrat } \\
\text { (Chi-square) }\end{array}$ & $\mathrm{P}$ \\
\hline Umur tanaman (Plant age) & $8,117 *$ & 0,017 & $6,649 *$ & 0,036 \\
\hline Asal bibit (Source of seeds) & 7,231 & 0,300 & 6,812 & 0,039 \\
\hline Jarak tanam (Plant spacing) & 0,313 & 0,855 & 0,504 & 0,777 \\
\hline Pola tanam (Cropping pattern) & 4,135 & 0,127 & 2,890 & 0,236 \\
\hline Tutupan lahan (Land cover) & 5,419 & 0,247 & 3,357 & 0,500 \\
\hline Pupuk organik (Use of organic fertilizer) & $6,757^{*}$ & 0,034 & $7,017 *$ & 0,030 \\
\hline Pupuk kimia (Use of chemical fertilizer) & 4,063 & 0,131 & 2,053 & 0,358 \\
\hline Herbisida (Use of herbicide) & 0,665 & 0,717 & 0,153 & 0,926 \\
\hline Pengendalian kimiawi (Chemical control) & $9,643^{*}$ & 0,008 & $7,988^{*}$ & 0,018 \\
\hline $\begin{array}{l}\text { Pemangkasan tanaman yang kena karat puru } \\
\text { (Galls pruning) }\end{array}$ & $6,113^{*}$ & 0,047 & 2,094 & 0,351 \\
\hline Sejarah lahan (Land history) & 2,006 & 0,735 & 2,965 & 0,564 \\
\hline Tanaman pencampur (Mixing plant) & $7,628 *$ & 0,022 & 2,685 & 0,261 \\
\hline Kemiringan lahan(Land slope) & $14,298 *$ & 0,006 & 2,196 & 0,700 \\
\hline
\end{tabular}

Keterangan (Remarks): IP = insidensi penyakit (disease incidence); KP = keparahan penyakit (disease severity); $\mathrm{P}=$ signifikansi (significance); angka-angka yang diikuti dengan tanda (*) menandakan parameter berkorelasi dengan insidensi penyakit karat puru pada $\mathrm{P}<0.05$ (The numbers followed by the (*) sign indicated the parameters correlated with the incidence of gall rust disease at $P<0.05$ )

Tabel (Table) 6. Tabulasi silang beberapa faktor budidaya yang berhubungan secara signifikan dengan insidensi dan keparahan penyakit karat puru (Cross tabulation for cultivation factors that significantly correlate to the gall rust disease incidence and severity)

\begin{tabular}{|c|c|c|c|c|c|c|c|}
\hline \multirow{3}{*}{ Faktor (Factor) } & \multirow{3}{*}{$\begin{array}{l}\text { Kode } \\
\text { (Code) }\end{array}$} & \multicolumn{6}{|c|}{ Klasifikasi (Classification) } \\
\hline & & \multicolumn{3}{|c|}{ IP } & \multicolumn{3}{|c|}{$\mathrm{KP}$} \\
\hline & & 1 & 2 & 3 & 1 & 2 & 3 \\
\hline \multicolumn{8}{|l|}{ Umur tanaman (Plant age): } \\
\hline$-0-2$ tahun $(0-2$ year $)$ & Y1 & 15 & 13 & 12 & 19 & 15 & 6 \\
\hline$->2$ tahun $(>2$ year $)$ & Y2 & 0 & 1 & 6 & 1 & 2 & 4 \\
\hline \multicolumn{8}{|l|}{ Pupuk organik (Organic fertilizer): } \\
\hline - Tidak digunakan (Not used) & O1 & 0 & 5 & 6 & 1 & 7 & 3 \\
\hline - Digunakan (Used) & $\mathrm{O} 2$ & 15 & 9 & 12 & 19 & 10 & 7 \\
\hline \multicolumn{8}{|c|}{ Pengendalian dengan fungisida (Fungicide } \\
\hline $\begin{array}{l}\text { - Tidak digunakan (Not used) } \\
\text { - Digunakan (Used) }\end{array}$ & $\mathrm{F} 2$ & 8 & 6 & 2 & 11 & 5 & 0 \\
\hline
\end{tabular}

\section{Analisis korespondensi faktor budidaya yang berkorelasi dengan keparahan penyakit karat puru pada sengon}

Sebanyak tiga faktor budidaya yang menunjukkan hubungan yang signifikan digunakan pada analisis korespondensi guna mengetahui lebih lanjut faktorfaktor yang berasosiasi paling kuat dengan keparahan penyakit karat puru pada sengon. Nilai inersia yang dihasilkan dari analisis korespondensi dapat 
Neo Endra Lelana, Suryo Wiyono, Giyanto dan Iskandar Z. Siregar

dilihat pada Tabel 7. Nilai inersia ini dapat digunakan untuk menggambarkan tingkat asosiasi antara kelas kategori tiap faktor dengan tingkat keparahan penyakit karat puru. Nilai total inersia yang dihasilkan yaitu sebesar 0,165. Pada analisis ini, hanya ada dua dimensi yang dihasilkan, sehingga total inersia yang dihasilkan dari dua dimensi tersebut ialah $100 \%$. Nilai inersia untuk dimensi satu sebesar 0,124 yang menunjukkan bahwa dimensi satu memberikan proporsi sebesar $75,15 \%$ dari total nilai inersia dan menjelaskan variabilitas data sebesar $75,15 \%$. Sementara itu, nilai inersia untuk dimensi dua sebesar 0,041 yang menunjukkan bahwa dimensi dua memberikan proporsi sebesar $24,85 \%$ dari total nilai inersia dan menjelaskan variabilitas data sebesar $24,85 \%$.

Hasil analisis korespondensi yang digambarkan dalam bentuk grafik dua dimensi selanjutnya disajikan pada Gambar 1. Keparahan penyakit karat puru rendah (KP1) terlihat berasosiasi dengan umur 0-2 tahun (Y1), penggunaan pupuk organik $(\mathrm{O} 2)$, dan pengendalian secara kimiawi (F2). Sementara itu keparahan penyakit karat puru sedang (KP2) berasosiasi dengan tidak melakukan pengendalian secara kimiawi (F1) dan tidak menggunakan pupuk organik (O1). Keparahan penyakit karat puru tinggi
(KP3) berasosiasi dengan umur lebih dari 2 tahun (Y2). Faktor tidak adanya pengendalian secara kimiawi (F1) terlihat lebih dekat dengan keparahan penyakit sedang (KP2) dibanding faktor tidak menggunakan pupuk organik (O1). Tindakan pengendalian kimiawi dan penggunaan pupuk organik diduga dapat menghambat perkembangan penyakit karat puru pada sengon, namun pengendalian kimiawi tampaknya lebih berperan dalam menghambat perkembangan penyakit.

\section{B. Pembahasan}

Praktik budidaya dapat dimanfaatkan untuk pengelolaan penyakit tanaman dengan menciptakan lingkungan yang menguntungkan bagi tanaman dan tidak menguntungkan bagi patogen (Katan, 2010). Praktik budidaya tersebut dapat memengaruhi iklim mikro dan kebugaran tanaman, sehingga secara langsung maupun tidak langsung dapat mempengaruhi perkembangan penyakit. Pengendalian penyakit tanaman dengan pendekatan praktik budidaya menjadi perhatian kembali setelah pengendalian sebelumnya dengan pendekatan pestisida menimbulkan permasalahan lingkungan maupun resistensi patogen terkait penggunaan pestisida yang tidak terkendali.

Tabel (Table) 7. Nilai inersia faktor yang berasosiasi dengan kaparahan penyakit karat puru (Inertia value for factors associated with gall rust disease severity)

\begin{tabular}{cccc}
\hline Dimensi (Dimension) & Inersia (Inertia) & $\begin{array}{c}\text { Proporsi inersia (Inertia } \\
\text { proportion) }(\%)\end{array}$ & $\begin{array}{c}\text { Signifikansi } \\
\text { (Significance) }\end{array}$ \\
\hline 1 & 0,124 & 75,15 & 0,010 \\
2 & 0,041 & 24,85 & \\
Total & 0,165 & 100,00 & \\
\hline
\end{tabular}




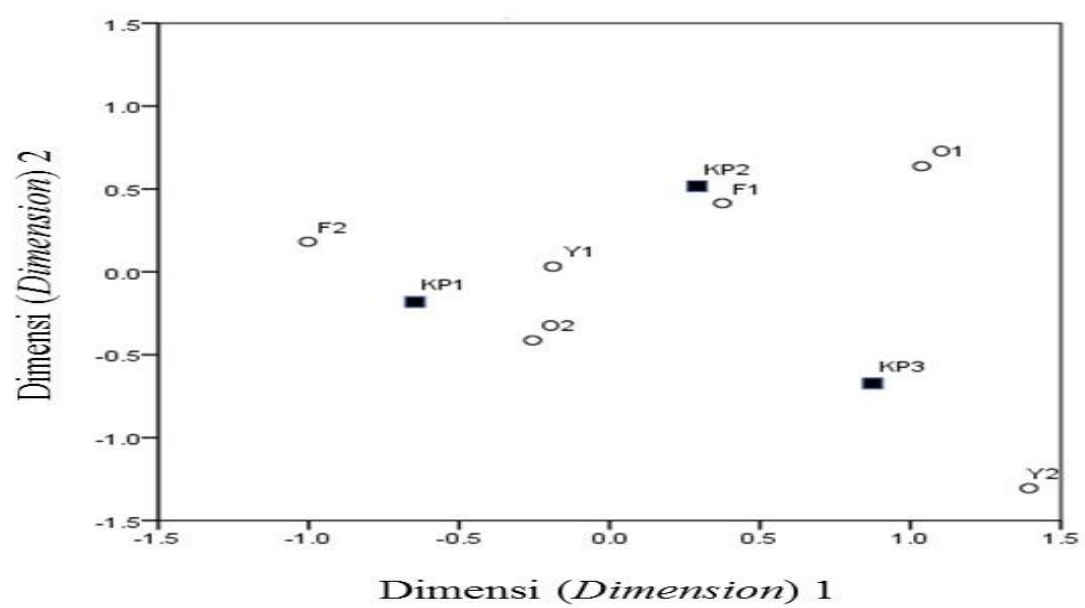

Keterangan (Remarks): Persegi berwarna hitam menunjukkan kelas keparahan penyakit, dan lingkaran putih menunjukkan faktor budidaya yang berkorelasi secara signifikan $(\mathrm{KP}=$ keparahan penyakit, $\mathrm{Y}=$ umur tanaman, $\mathrm{O}=$ pupuk organik, $\mathrm{F}=$ pengendalian kimiawi) (The black square shows the severity of the disease and the white circle shows the cultivation practices factor $(K P=$ disease severity, $Y=$ age of plant, $O=$ organic fertilizer, $F=$ chemical control))

Gambar (Figure) 1. Hasil analisis korespondensi faktor budidaya yang berkorelasi dengan keparahan penyakit karat puru pada sengon (Correlation analysis of cultivation factors correlated to the severity of gall rust disease)

Pada penelitian ini, beberapa faktor praktik budidaya seperti asal bibit, jarak tanam, pola tanam, tutupan lahan, penggunaan pupuk kimia, penggunaan herbisida dan sejarah lahan tidak menunjukkan hubungan yang signifikan terhadap insidensi dan keparahan penyakit karat puru. Jarak tanam, tutupan lahan, dan pola tanam dapat memengaruhi iklim mikro maupun kontak langsung antar tanaman pada areal tanam, sehingga secara langsung akan memengaruhi perkembangan dan penyebaran patogen. Beberapa laporan menunjukkan bahwa faktor-faktor tersebut secara signifikan dapat menekan insidensi penyakit tanaman (Ahmed et al., 2017; Ehrenbergerová, Kučera, Cienciala, Trochta, \& Volař́k, 2017; Hiddink, Termorshuizen, \& van Bruggen, 2010). Namun demikian pada penelitian ini faktor-faktor tersebut tidak menunjukkan hubungan yang signifikan terhadap insidensi dan keparahan penyakit karat puru. Hal tersebut diduga terjadi karena perubahan iklim mikro yang dihasilkan belum cukup untuk memengaruhi perkembangan penyakit karat puru. Penggunaan pupuk kimia dan herbisida pada hasil penelitian ini juga tidak menunjukkan hubungan yang signifikan. Beberapa laporan menunjukkan hal sebaliknya bahwa pemupukan dan penggunaan herbisida dapat mempengaruhi perkembangan penyakit tanaman (Atiq et al., 2017; Johal \& Huber, 2009). Menurut (Katan, 2010) pemupukan tidak secara langsung berperan dalam perlindungan tanaman terhadap penyakit, namun demikian dapat memberikan pengaruh terhadap insidensi penyakit tanaman. Pada kasus karat puru ini, faktor tersebut diduga tidak berpengaruh terhadap insidensi penyakit karat puru.

Sebanyak enam faktor budidaya secara signifikan berhubungan dengan insidensi penyakit. Faktor-faktor tersebut yaitu umur tanaman, penggunaan pupuk organik, pengendalian puru secara kimiawi, pemangkasan puru, jenis tanaman pencampur, dan kemiringan lahan. Beberapa penelitian juga menunjukkan 
Neo Endra Lelana, Suryo Wiyono, Giyanto dan Iskandar Z. Siregar

bahwa faktor-faktor tersebut dilaporkan dapat menekan insidensi penyakit tanaman. Pemangkasan telah dilaporkan dapat mengurangi insidensi penyakit karat pada sugar pine (O'Hara, Grand, \& Whitcomb, 2010). Pemangkasan puru bertujuan untuk menghilangkan bagian tanaman yang terserang sehingga akan berpengaruh dalam mengurangi jumlah inokulum. Jenis tanaman pencampur juga memengaruhi toleransi tanaman terhadap patogen (Newton, 2016). Insidensi penyakit karat puru pada lahan yang miring cenderung lebih tinggi dibandingkan pada lahan yang datar. Hal ini diduga berhubungan dengan terpaan angin yang membawa patogen karat puru dari tempat lain dimana daerah yang kondisi lahannya lebih miring sampai curam cenderung lebih banyak terkena terpaan angin, sehingga lebih rentan terinfeksi. Smith, Resler, Vance, Carstensen, \& Kolivras (2011) menyatakan bahwa kemiringan lahan dapat memengaruhi paparan angin dan cahaya matahari pada tegakan, sehingga akan berpengaruh terhadap perkembangan penyakit.

Untuk faktor umur tanaman, hasil analisis korespondensi menunjukkan bahwa pohon sengon yang berumur lebih dari 2 tahun berasosiasi kuat dengan keparahan penyakit karat puru yang tinggi. Hal ini menunjukkan bahwa serangan penyakit karat puru meningkat seiring dengan bertambahnya umur pohon. Patogen karat, seperti halnya patogen tular udara umumnya, mempunyai tipe perkembangan polisiklik. Patogen tipe polisiklik menghasilkan lebih dari satu generasi per musim tanam dan menyelesaikan beberapa kali siklus penyakit per tahun, sehingga akan menghasilkan infeksi yang berulangulang (Mundt, 2009) Oleh karena itu, keparahan penyakit pada tanaman dewasa cenderung lebih tinggi dibanding tanaman muda.

Penggunaan pupuk organik dan pengendalian kimiawi juga menunjukkan asosiasi yang kuat dengan keparahan penyakit. Hal ini mengindikasikan bahwa penggunaan pupuk organik dan pengendalian kimiawi dapat memengaruhi perkembangan penyakit karat puru pada sengon. Pupuk organik diketahui dapat meningkatkan kualitas biologi tanah dengan merubah struktur dan komposisi mikroba di dalam tanah (Aparna, Pasha, Rao, \& Krishnaraj, 2014; Bernard et al., 2014). Penambahan pupuk organik dalam menekan penyakit tanaman sudah banyak dilaporkan terutama untuk patogen tular tanah, seperti Pythium, Fusarium, dan Rhizoctonia (Tewoldemedhin, Lamprecht, \& Mazzola, 2015; Borregobenjumea, Basallote-ureba, Melero-vara, \& Abbasi, 2014; Tamm et al., 2011; Chen \& Nelson, 2008).

Untuk penyakit karat puru pada sengon, pupuk organik diduga lebih berperan dalam menginduksi ketahanan tanaman. Pupuk organik yang banyak digunakan petani sengon ialah pupuk kandang dan sebagian menggunakan kompos. Pupuk organik banyak mengandung mikroba menguntungkan, seperti dari kelompok Bacillus, Streptomyces, Trichoderma, Penicillium, dan Aspergillus (Escobar \& Solarte, 2015; Swer, Dkhar, \& Kayang, 2011; Partanen, Hultman, Paulin, Auvinen, \& Romantschuk, 2010). Mikroba-mikroba tersebut dapat menginduksi ketahanan sistemik tanaman, sehingga dapat menekan perkembangan patogen (Shafi, Tian, \& Ji, 2017; Kamal \& Sharma, 2014). Selain melalui induksi ketahanan tanaman, mekanisme penghambatan lainnya ialah dengan memengaruhi komposisi kimia jaringan tanaman, sehingga dapat menghambat perkembangan patogen dalam jaringan. Menurut van Bruggen \& Finckh (2016), tanaman yang diberi pupuk organik mempunyai konsentrasi nitrogen pada jaringan daun yang lebih rendah, sehingga lebih tahan terhadap serangan beberapa penyakit 
daun seperti penyakit karat dan embun tepung.

Asosiasi yang kuat juga terjadi pada pengendalian kimiawi. Berdasarkan hasil wawancara, sebagian besar pengendalian yang dilakukan oleh petani sengon ialah dengan menyemprotkan campuran belerang dan kapur pada tanaman yang terinfeksi. Campuran belerang kapur diketahui mempunyai aktivitas anti cendawan, sehingga diduga dapat menghambat perkembangan penyakit karat puru. Beberapa laporan lain juga menyebutkan bahwa belerang kapur digunakan untuk mengendalikan penyakit karat pada blackberry yang disebabkan oleh Phragmidium violaceum dan penyakit cacar air pada apel yang disebabkan oleh Venturia inaequalis (Cromwell, Berkett, \& Darby, 2011; Johnson \& Wahaffee, 2010). Campuran belerang kapur dapat menghasilkan hidrogen sulfida yang bersifat toksik terhadap cendawan (Holb \& Schnabel, 2008). Secara umum, mekanisme penghambatan yang terjadi ialah dengan memengaruhi kompleks respirasi mitokondria dengan mengganggu transpor elektron, sehingga toksisitas yang dihasilkan bersifat multi lokasi dan berspektrum luas.

Beberapa parameter faktor budidaya telah menunjukkan adanya hubungan yang signifikan terhadap keberadaan penyakit karat puru pada sengon. Namun berdasarkan hasil analisis korespondensi, pengendalian penyakit karat puru secara kimiawi lebih berperan dalam mengendalikan penyakit karat puru dibanding faktor budidaya lainnya. Namun demikian, jika berbagai faktor pada praktik budidaya dapat dikombinasikan dan diaplikasikan secara bersama-sama dengan baik, seperti penggunaan pupuk organik dan pemangkasan dahan yang terkena penyakit karat puru, maka pengaruh yang dihasilkan dalam mengurangi tingkat insidensi penyakit karat puru diduga akan lebih baik. Aplikasi dari praktik budidaya yang baik diharapkan juga dapat berperan dalam mengurangi intensitas penggunaan fungisida kimia dalam pengendalian penyakit karat puru.

\section{KESIMPULAN DAN SARAN}

\section{A. Kesimpulan}

Sebanyak 6 dari 13 faktor budidaya menunjukkan hubungan yang signifikan terhadap insidensi penyakit karat puru, yaitu umur tanaman, penggunaan pupuk organik, pengendalian karat puru secara kimiawi, pemangkasan tanaman yang kena karat puru, jenis tanaman pencampur, dan kemiringan lahan. Sementara itu untuk keparahan penyakit, hanya 3 dari 13 faktor yang menunjukkan hubungan signifikan. Ketiga faktor tersebut ialah umur tanaman, penggunaan pupuk organik, dan pengendalian kimiawi. Hasil analisis korespondensi menunjukkan penggunaan pupuk organik dan pengendalian secara kimiawi berasosiasi dengan keparahan penyakit yang rendah, sedangkan tanpa pemupukan organik dan tanpa pengendalian kimiawi berasosiasi dengan tingkat keparahan sedang. Asosiasi pengendalian kimiawi dengan tingkat keparahan penyakit karat puru lebih kuat dibandingkan dengan faktor budidaya lainnya. Namun demikian jika berbagai faktor pada praktik budidaya tersebut diaplikasikan secara bersama-sama sebagai bagian dari strategi pengendalian penyakit karat puru, maka pengendalian penyakit karat puru akan berpotensi menjadi lebih efektif.

\section{B. Saran}

Beberapa faktor budidaya, terutama penggunaan pupuk organik dan pemangkasan karat puru, diketahui dapat mengurangi tingkat insidensi penyakit karat puru pada sengon. Oleh karena itu, pendekatan tersebut perlu dipertimbangkan menjadi bagian dari strategi pengendalian penyakit karat puru. 
Neo Endra Lelana, Suryo Wiyono, Giyanto dan Iskandar Z. Siregar

\section{UCAPAN TERIMA KASIH}

Penelitian ini dibiayai oleh Pusat Penelitian dan Pengembangan Hutan; Badan Penelitian, Pengembangan dan Inovasi; Kementerian Lingkungan Hidup dan Kehutanan Tahun Anggaran 2015 (DIPA 2015). Ucapan terima kasih disampaikan kepada Yeni, Nuraeni, S. Hut, Yayang Nurahmah, dan Melina Dwi Rosalinda yang telah membantu kegiatan di lapangan.

\section{DAFTAR PUSTAKA}

Ahmed, I., Khan, M.A., Khan, N., Ahmed, N., Waheed, A., Yazdan, F., ... Aslam, S. (2017). Impact of plant spacing on garlic rust (Puccinia allii), bulb yielld and yield component of garlic (Allium sativum). Pakistan Journal of Agricultural Research, 30(4), 380385.

Anggraeni, I. (2008). Pengendalian penyakit karat tumor (gall rust) pada sengon (Paraserianthes falcataria) di RPH Pandantoyo, BKPH Pare, KPH Kediri.Workshop Penanggulangan Serangan Karat Puru pada Tanaman Sengon 19 Nopember 2008.

Aparna, K., Pasha, M.A., Rao, D.L.N., \& Krishnaraj, P.U. (2014). Organic amendments as ecosystem engineers: microbial, biochemical and genomic evidence of soil health improvement in a tropical arid zone field site. Ecological Engineering, 71, 268-77.

Atiq, M., Javed, N., Urooj, S., Bukhari, A.A., Ali, Y., Zeeshan, A., ... Jabbar, A. (2017). Management of leaf rust of wheat through different levels of NPK and sowing times. Advances in Zoology and Botany, 5(4), 39-44.
Badan Pusat Statistik. (2013). Sensus Pertanian Tahun 2013. http://st2013.bps.go.id/.

Bernard, E., Larkin, R.P., Tavantzis, S., Erich, M.S., Alyokhin, A., \& Gross, S. (2014). Rapeseed rotation, compost, and biocontrol amendments reduce soilborne diseases and increase tuber yield in organic and conventional potato production systems. Plant Soil, 374, 611-27.

Berndt, R. (2010). Uromycladium naracoortensis, a new species of rust fungi (Uredinales) from Australia, with new observations on described Uromycladium species. Polish Botanical Journal, 55(2), 299-308.

Beruski, G.C., Pereira, A.B., Jaccoudfilho, D.S., Sartori, F.F., \& Sentelhas, P.C. (2015). Incidence and severity of white mold for soybean under different cultural practices and local meteorological conditions. Bioscience Journal, 31(4), 1004-1014.

Borrego-benjumea, A., Basallote-ureba, M.J., Melero-vara, J.M., \& Abbasi, P.A. (2014). Characterization of Fusarium isolates from Asparagus fields in Southwestern Ontario and influence of soil organic amendments on Fusarium crown and root rot. Phytopathology, 104(4), 403-415.

Brooks, S.A., Anders, M.M., \& Yeater, K.M. (2009). Effect of cultural management practices on the severity of false smut and kernel smut of rice. Plant Disease, 93(11), 1202-1208.

Chen, M., \& Nelson, E.B. (2008). Seedcolonizing microbes from municipal biosolids compost suppress Pythium ultimum damping-off on different 
plant species. Phytopathology, 98(9), 1012-1018.

Cromwell, M.L., Berkett, L.P., Darby, H.M., \& Ashikaga, T. (2011). Alternative organic fungicide for apple scab management and their non-target effects. Hort Science, 46(9), 1254-1259.

Doungsa-ard, C., Mc Taggart, A.R., Geering, A.D.W., Dalisay, T.U., Ray, J., Shivas, R.G. (2015). Uromycladium falcatarium $\mathrm{sp}$. nov., the cause of gall rust on Paraserianthes falcataria in South-east Asia. Australasian Plant Pathology, 44(1), 25-30.

Ehrenbergerová, L., Kučera, A., Cienciala, E., Trochta, J., \& Volařík, D. (2017). Identifying key factors affecting coffee leaf rust incidence in agroforestry plantations in Peru. Agroforestry Systems, 1-15.

El Khoury, W., \& Makkouk, K. (2010). Integrated plant disease management in developing country. Journal of Plant Pathology, 92(4), 35-42.

Escobar, N., \& Solarte, V. (2015). Microbial diversity associated with organic fertilizer obtained by composting of agricultural waste. International Journal of Bioscience, Biochemistry and Bioinformatics, 5(2), 70-79.

Hiddink, G.A., Termorshuizen, A.J., \& van Bruggen, A. (2010). Mixed cropping and supression of soilborne disease. In Lichtfouse E. (Ed.), Genetic Engineering, Biofertilisation, Soil Quality and Organic Farming. London New York: Springer Science+Business Media B.V.

Holb, I.J., \& Schnabel, G. (2008). A detached fruit study on the postinoculation activity of lime sulfur against brown rot of peach (Monilinia fructiola). Australasian
Plant Pathology, 37,454-459.

IBM Corp. (2011). IBM SPSS Statistics for Windows, Version 20.0. Armonk, NY: IBM Corp.

Johal, G.S., \& Huber, D.M. (2009). Glyphosate effects on diseases of plants. European Journal of Agronomy, 31(3), 144-152.

Johnson, K.B., \& Mahaffee, W.F. (2010). Factors influencing epidemiology and management of blackberry rust in cultivated Rubus laciniatus. Plant Disease, 94(5), 581-588.

Kamal, R., Sharma A.K. (2014). Control of Fusarium wilt using biological agent Streptomyces sp. CPP-53 isolated from compost with plant growth promoting effect on tomato under greenhouse condition. Journal of Microbiolgy and Antimicrobials, 6(6), 97-103.

Katan, J. (2010). Cultural approaches for disease management : present status and future prospects cultural practices for disease. Journal of Plant Pathology, 92, 7-9.

Lelana, N.E., Wiyono, S., Giyanto, \& Siregar, I.Z. (2018). Genetic diversity of Falcataria moluccana and its relationship to the resistance of gall rust disease. Biodiversitas, 19(1), 12-17.

Mundt, C.C. (2009). Importance of autoinfection to the epidemiology of polycyclic foliar disease. Phytopathology, 99, 1116-1120.

Newton, A.C. (2016). Exploitation of diversity within crops - the key to disease tolerance?. Frontiers in Plant Science, 7(655), 1-12.

O’Hara, K.L., Grand, L.A., \& Whitcomb, A.A. (2010). Pruning reduces blister rust in sugar pine with minimal effects on tree growth. California Agriculture, 64(1), 31-36.

Partanen, P., Hultman, J., Paulin, L., 
Neo Endra Lelana, Suryo Wiyono, Giyanto dan Iskandar Z. Siregar

Auvinen, P., \& Romantschuk, M. (2010). Bacterial diversity at different stages of the composting process. BMC Microbiology, 10(94), 1-11.

Rahayu, S., Lee, S.S., \& Shukor, N.A.A. (2010). Uromycladium tepperianum, the gall rust fungus from Falcataria moluccana in Malaysia and Indonesia. Mycoscience, 51(2), 149153.

Shafi, J., Tian, H., \& Ji, M. (2017). Bacillus species as versatile weapons for plant pathogens: a review. Biotechnology \& Biotechnological Equipment, 31(3), 446-459.

Smith, E.K., Resler, L.M., Vance, E.A., Carstensen, L.W., \& Kolivras, K.N. (2011). Blister rust incidence in treeline whitebark pine, Glacier National Park, U.S.A.: environmental and topographic influences. Arctic, Antarctic, and Alpine Research, 43(1), 107-117. https://doi.org/10.1657/1938-424643.1.107

Swer, H., Dkhar, M.S., \& Kayang, H. (2011). Fungal population and diversity in organically amanded agricultural soils of Meghalaya,
India. Journal of Organic Systems, 6(2), 3-12.

Tamm, L., Thürig, B., Fliessbach, A., Goltlieb, A.E., Karavani, S., \& Cohen, Y. (2011). Elicitors and soil management to induce resistance against fungal plant diseases. NJASWageningen Journal of Life Sciences, 58, 131-137.

Tenge, B.N., Ojwang, P.P.O., Otaye, D., \& Oyoo, M.E. (2016). Wheat stem rust disease incidence and severity associated with farming practices in the Central Rift Valley of Kenya. African Journal of Agricultural Research, 11(29), 2640-2649.

Tewoldemedhin, Y.T., Lamprecht, S.C., \& Mazzola, M. (2015). Rhizoctonia anastomosis groups associated with diseased rooibos seedlings and the potential of compost as soil amendment for disease suppression. Plant Disease, 99(7), 1020-1025.

Van Bruggen, A.H.C., \& Finckh, M.R. (2016). Plant diseases and management approaches in organic farming systems. Annual Review of Phytopathology, 54, 1-30. 